\title{
Article \\ Ontogenetic Habitat Use and Density of the Green Lizard (Lacerta bilineata) in Contrasted Landscapes in France and Italy
}

\author{
Lorenzo Rugiero $^{1}$, Massimo Capula ${ }^{2}$, Massimiliano Di Vittorio ${ }^{3}$, Daniele Dendi ${ }^{1,4,5}{ }^{,}$Roger Meek $^{1}$ \\ and Luca Luiselli $1,4,5, *$ (D)
}

Citation: Rugiero, L.; Capula, M.; Di Vittorio, M.; Dendi, D.; Meek, R.; Luiselli, L. Ontogenetic Habitat Use and Density of the Green Lizard (Lacerta bilineata) in Contrasted Landscapes in France and Italy. Conservation 2021, 1, 1-16. https://doi.org/10.3390/ conservation 1010001

Academic Editor: Antoni Margalida Received: 16 December 2020 Accepted: 3 February 2021 Published: 9 February 2021

Publisher's Note: MDPI stays neutral with regard to jurisdictional claims in published maps and institutional affiliations.

Copyright: (c) 2021 by the authors. Licensee MDPI, Basel, Switzerland. This article is an open access article distributed under the terms and conditions of the Creative Commons Attribution (CC BY) license (https:/ / creativecommons.org/licenses/by/ $4.0 /)$.
1 Institute for Development, Ecology, Conservation and Cooperation, via G. Tomasi di Lampedusa 33, 00144 Rome, Italy; lore.rho@gmail.com (L.R.); d.dendi@ideccngo.org (D.D.); rogermeek85@aol.com (R.M.)

2 Museo Civico di Zoologia, Via Ulisse Aldrovandi, 18, 00197 Rome, Italy; m.capula@comune.roma.it

3 Ecologia Applicata Italia s.r.l., Via Jevolella, 2, 90018 Termini Imerese, Italy; divittoriomassimiliano@gmail.com

4 Department of Applied and Environmental Biology, Rivers State University of Science and Technology, P.M.B., Port Harcourt 5080, Nigeria

5 Department of Zoology, University of Lomé, Lomé, Togo

* Correspondence: 1.luiselli@ideccngo.org

\begin{abstract}
Habitat modification is a major factor in the decline of reptile populations. The degree of the decline has been shown to be directly related to the intensity of habitat modification. Farming practices and urbanization are just two of the factors involved indicating that the development of practices that minimize or cancel anthropogenic impacts is urgently needed to prevent further declines. This requires knowledge of population ecology of reptiles in both disturbed and pristine habitats. In this paper, we describe aspects of green lizard (Lacerta bilineata) population ecology in a forest-pasture relatively pristine mosaic habitat in central Italy and a fragmented habitat in western France. In Italy, habitat niche overlap was very high between males and females but very low between males and juveniles. For male and female abundances, general linear models showed that the adult abundances increased with the increase of Rubus bushes, whereas juvenile abundance increased with the increase of Spartium bushes. Contingency table analysis showed that juveniles were also much more frequently observed in grasslands than adults of either sexes. The observed ontogenetic structural niche pattern was likely due to intraspecific competition avoidance, competition interference, and cannibalism. The persistence of the same patterns across years demonstrates a temporal stability of the ontogenetic structural niche pattern. Over the length of the study period, population densities were stable in the Italian population, but densities were much higher by around five times in the hedgerow in the fragmented habitat in France. In the hedgerow, monthly lizard presence was uneven, with the greatest number of sightings in June and July. Overall, our study provided no support for the notion that lizard abundance/density should be lower in modified compared to unmodified habitats, and clearly revealed that a careful management of the hedgerows is crucial for the conservation of this lizard species in agro-forest ecosystems.
\end{abstract}

Keywords: lacertidae; habitat selection; density; France; Italy; niche characteristics; fragmentation

\section{Introduction}

Habitat structure and quality is a key factor in reptile ecology, but the expansion of urban areas and modification into natural environments by agriculture and the effects of climate change are factors now widely regarded as impacting on reptile populations [1]. Local extinctions of reptiles have been reported from urban areas where habitat fragmentation has resulted in major changes to vegetation structure and natural areas where temperature change has impacted on populations (e.g., [2]).

In Western Europe, the green lizard Lacerta bilineata is listed on Appendix II of the Bern Convention (Council of Europe, 1979) and, under its former name L. viridis, is classified 
as Least Concern (LC), despite a decreasing population trend, in the IUCN Red List of Threatened Species [3]. It occurs in a wide range of environments including open woodland, scrubland, suburban areas, and anthropogenically modified environments including agricultural areas [4-6]. A heliotherm that sun basks primarily in the earlier part of the day, it operates as a sentinel predator [7], feeding on insects and even small lizards, including juvenile conspecifics [8]. It is highly territorial, with serious injury and potentially even death arising from male-male combat, but females may also be subject to injury from intra-specific aggression [9]. This suggests that population spacing, for example male, female, and juvenile ratios, are potentially important in determining densities. Furthermore, L. bilineata usually occurs in sympatry with other species of reptiles and hence shares similar habitat requirements [9-11]. This suggests that L. bilineat $a$ can be regarded as an indicator species enabling some insight into population requirements from a conservation perspective. Therefore, studies that examine population ecology in distinct habitat types of this species may have special value.

In this paper, we describe aspects of population ecology of $L$. bilineata in two regions of Europe (Italy and France), with an emphasis on intrapopulation habitat use for the Italian population. Although the two studies were partially different in terms of original scopes and methodologies, they allowed the gathering of information on the habitat use and density of this lizard species, with both ecological and conservation implications. The first population was studied in a natural environment of mixed forest and grassland situated $50 \mathrm{~km}$ north of Rome in central Italy, where global warming effects have recently been reported as a factor determining changes in phenology and population ecology in sympatric snakes and tortoises (Vipera aspis; Hierophis viridiflavus; Zamenis longissimus; Testudo hermanni [12-16]. The second population was studied in a hedgerow system in a fragmented landscape in western France $[9,11]$. Although the monocultures produced by agriculture have little value to most wildlife, the hedgerows that bisect agricultural land are often populated by both lizards and snakes and may serve as permanent home ranges or function as connection pathways to more useable habitat and are likely key in avoiding genetic isolation (e.g., [17]). Additionally woodland edge habitat and hedgerow systems used by L. bilineata in Europe are structurally similar both in terms of plant species and degree of open and covered areas. The differences are that the former is more a natural habitat and the latter man made, which is in evolutionary terms a new habitat type. However, a hedgerow for any given area has greater edge habitat available to a thermoregulating reptile, and depending on location (orientation to sunlight for example), this can influence both reptile thermal ecology and potentially population ecology. The former is due to increased thermal opportunities, the latter reproductive biology arising from this. The present study, using data from the hedgerow system and natural habitat, tests if habitat modification is a major cause of reptile declines, with the hypothesis that lizard abundance/density should be lower in heavily modified compared to relatively unmodified habitats (e.g., [1]). In fact, if densities are in agreement or even greater in modified habitats such as hedgerows, then some compensatory ecological factors must be involved.

More explicitly, we ask the following key questions:

(1) Are there density differences between L. bilineata populations inhabiting contrasted habitats (mixed forest-grassland mosaics versus hedgerows within an agricultural matrix)? This question is important in order to better define the characteristics of the sites that are most suitable for L. bilineata ecological needs, and therefore for defining more precisely the management options for this declining lizard species.

(2) Do L. bilineata individuals select the same habitat types or is there significant intrapopulation variation in habitat selection? That is, are there significant habitat differences between sexes and age classes? If so, what are the ecological reasons behind these intraspecific differences? These questions are important, because habitat management can generate variation in a cascade of organismal traits linked to the environment [18], and knowing the intraspecific habitat use variation may better guide management 
strategies. In addition, efficient management for conservation of a given species may require a more integrated approach in case of substantial intraspecific (intersexual or age-related) differences in habitat use $[17,18]$. In this case, the green lizard may be a very suitable study case, as cannibalistic habits have been already detected in this species, and cannibalism may lead to habitat shifts by age or by sex [8].

(3) Are human-made structures important for the habitat requirements of L. bilineata or are there specific plant species (bushes or trees) that are positively correlated with the species' presence? This question is important in order to better define whether active human intervention (replanting of given species or building of specific features, for instance stony walls, etc.) may help management of the suitable habitat for the study species, or whether passive management (that is just natural habitat monitoring) may be a sufficient condition for the effective conservation of L. bilineata populations.

\section{Materials and Methods}

2.1. Study Area

2.1.1. Italy

Field data were collected in the woodlands surrounding the villages Manziana, Oriolo Romano, and Canale Monterano (approximate coordinates: $12^{\circ} 5^{\prime} \mathrm{E}, 42^{\circ} 6^{\prime} \mathrm{N}$ ), about $50 \mathrm{~km}$ north of Rome (Latium, Central Italy). The study area was a mixed oak woodland with Quercus cerris and Q. frainetto as dominant species. In the drier sector of the forest, Quercus ilex was found, and Acer campestre and Tilia sp. were also common species inside the main forest patch. Rubus ulmifolius, Rubus cesius, Pteridium aquilinum, Prunus spinosa, Hedera helix, Crataegus monogyna, Rosa canina, and Sorbus domestica were the most common species of the undergrowth.

\subsubsection{France}

Field data were collected along a hedgerow with an approximate maximum length of $190 \mathrm{~m}$ and width of $14 \mathrm{~m}$. The locality was on the edge of the village of Chasnais $\left(1^{\circ} 13^{\prime} \mathrm{W}\right.$, $46^{\circ} 27^{\prime} \mathrm{N}$ ). The hedgerow was composed of a mixture of scrub species (e.g., Rubus fruticosus) along with ivy Hedera helix, ash tree (Fraxinus excelsior), and oak (Quercus robur). The hedgerow length was $190 \mathrm{~m}$.

\subsection{Protocol}

\subsubsection{Italy}

The field study was carried out in April-June 1991, 1992, 1993, 1996, and 1997. On each day of survey, 2-3 researchers walked independently along random transects and never inspected more than once a same spot, in order to avoid multiple sightings of a same individual and hence pseudoreplication. On each field day, the research lasted from about 9 a.m. to 4 p.m., and searches were carried out only during sunny days in order to make the inter-daily results more directly comparable. We directly observed the lizards but never attempted to capture them in order to minimize disturbance. Each observed lizard was identified by sex because of its external features, and its age class (adult or juvenile) was also identified based on both the body size and the dorsal coloration (that is very different between adults and juveniles). Each recorded lizard was assigned to a micro-habitat category. Each micro-habitat category was characterized by the dominance of a specific bushy plant taxon. The following six micro-habitat types were identified and considered for this study (Figure 1): 
(A)

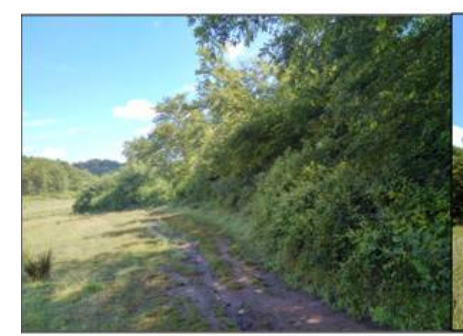

(D)

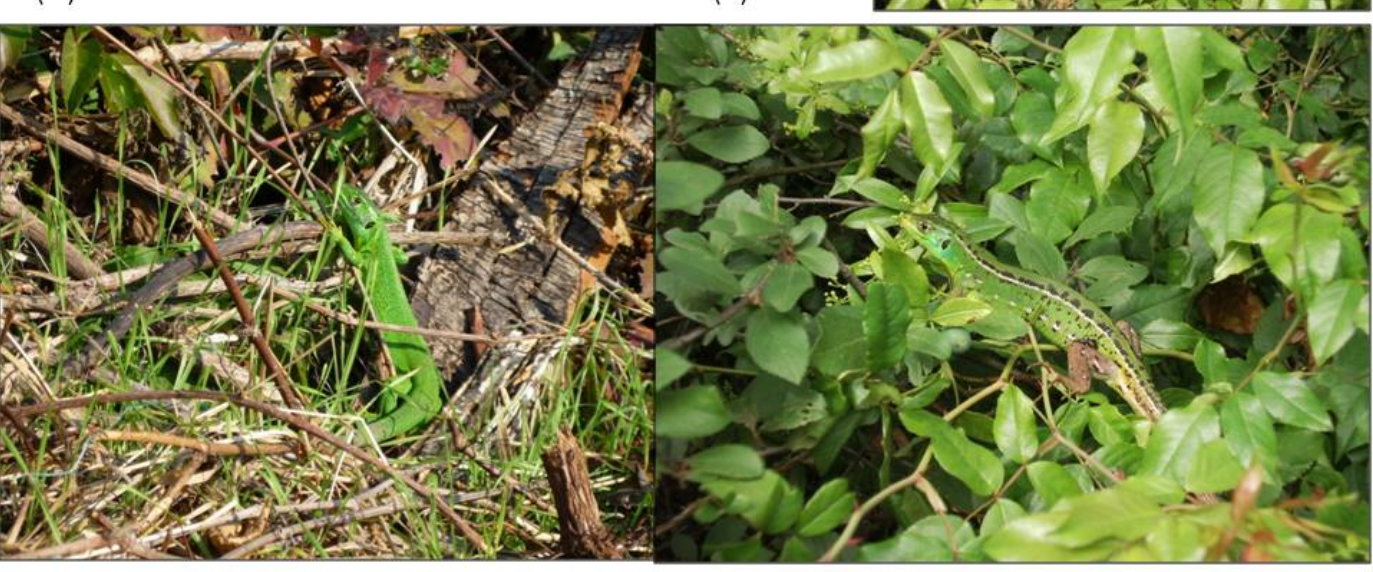

(C)

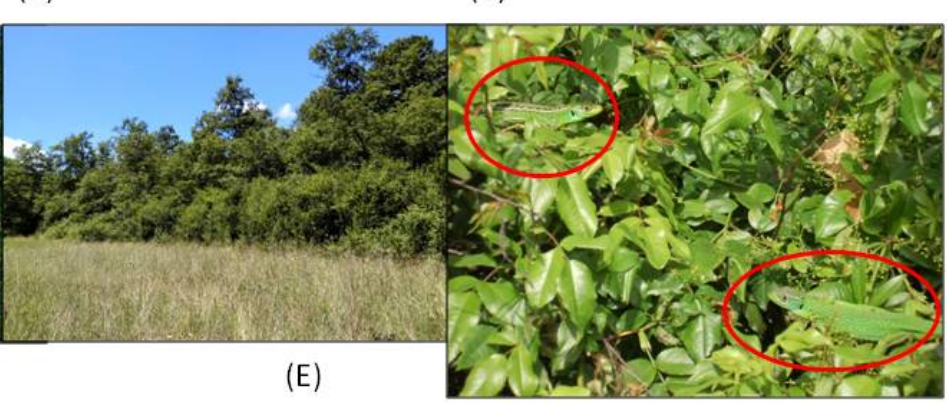

Figure 1. Lacerta bilineata at the study area in central Italy: $(\mathbf{A}, \mathbf{B})$ ecotonal areas surveyed during the field study; (C) pair of L. bilineata (female in the upper perch and male in the lower perch); (D) adult male; (E) adult female.

(1) Rubus sp., that was the most wet micro-habitat available to lizards at the study area; (2) Cytisus scoparius; (3) Spartium junceum; (4) open grassland with no bushy species; (5) stony wall (locally called "muretti a secco"); (6) Smilax aspera. Habitat (5) was the only human-made feature available to lizards at the study areas. The relative length of the various transects walked in each year by micro-habitat type are summarized in Table 1.

Table 1. Synopsis of the data concerning the number of Lacerta bilineata observed by year, in the various habitat types at the study area in central Italy.

\begin{tabular}{|c|c|c|c|c|c|c|c|}
\hline \multirow[b]{2}{*}{1991} & \multicolumn{6}{|c|}{ Habitat Types } & \multirow[t]{2}{*}{ Total } \\
\hline & Rubus & Cytisus & Spartium & grassland & stony walls & Smilax aspera & \\
\hline transect length $(\mathrm{m})$ & 416 & 339 & 255 & 410 & 350 & 235 & 2005 \\
\hline males (n) & 11 & 3 & 1 & 2 & 6 & 3 & 26 \\
\hline females (n) & 7 & 3 & 3 & 3 & 4 & 4 & 24 \\
\hline juveniles (n) & 2 & 6 & 7 & 24 & 3 & 1 & 43 \\
\hline \multicolumn{8}{|l|}{1992} \\
\hline transect length (m) & 339 & 245 & 270 & 337 & 411 & 190 & 1792 \\
\hline males (n) & 8 & 4 & 3 & 3 & 4 & 1 & 23 \\
\hline females (n) & 8 & 2 & 3 & 4 & 2 & 2 & 21 \\
\hline juveniles (n) & 0 & 0 & 1 & 26 & 3 & 0 & 30 \\
\hline \multicolumn{8}{|l|}{1993} \\
\hline transect length $(\mathrm{m})$ & 402 & 330 & 308 & 294 & 332 & 208 & 1874 \\
\hline males (n) & 8 & 6 & 2 & 0 & 2 & 1 & 19 \\
\hline
\end{tabular}


Table 1. Cont.

\begin{tabular}{|c|c|c|c|c|c|c|c|}
\hline \multirow[b]{2}{*}{1991} & \multicolumn{6}{|c|}{ Habitat Types } & \multirow[t]{2}{*}{ Total } \\
\hline & Rubus & Cytisus & Spartium & grassland & stony walls & Smilax aspera & \\
\hline females (n) & 6 & 8 & 2 & 3 & 3 & 1 & 23 \\
\hline juveniles (n) & 1 & 2 & 2 & 15 & 4 & 0 & 24 \\
\hline \multicolumn{8}{|l|}{1996} \\
\hline transect length $(\mathrm{m})$ & 320 & 275 & 290 & 255 & 285 & 225 & 1650 \\
\hline males (n) & 14 & 3 & 1 & 2 & 4 & 1 & 25 \\
\hline females (n) & 6 & 5 & 4 & 4 & 2 & 2 & 23 \\
\hline juveniles (n) & 3 & 0 & 2 & 19 & 6 & 0 & 30 \\
\hline \multicolumn{8}{|l|}{1997} \\
\hline transect length $(\mathrm{m})$ & 402 & 302 & 267 & 281 & 256 & 244 & 1752 \\
\hline males (n) & 2 & 0 & 0 & 1 & 4 & 1 & 8 \\
\hline females (n) & 3 & 1 & 1 & 3 & 3 & 2 & 13 \\
\hline juveniles (n) & 0 & 0 & 0 & 14 & 3 & 0 & 17 \\
\hline \multicolumn{8}{|l|}{1998} \\
\hline transect length $(\mathrm{m})$ & 355 & 315 & 274 & 245 & 260 & 275 & 1724 \\
\hline males (n) & 8 & 2 & 3 & 2 & 2 & 0 & 17 \\
\hline females (n) & 4 & 3 & 1 & 3 & 2 & 0 & 13 \\
\hline juveniles (n) & 1 & 1 & 0 & 13 & 3 & 0 & 18 \\
\hline
\end{tabular}

\subsubsection{France}

Lizards were detected visually and identified by photographs using a Lumix camera, with $\times 30$ zoom. This non-invasive method uses individual marks for identification, e.g., spots and their locations, tail condition (intact or with loss along with degree of loss and re-growth), and head markings. The method avoids the need for capture and potential distortions in behavior due to capture stress (e.g., $[19,20]$ ). However, the weakness is absence of useful measurement of individuals such as snout to vent lengths. Searching was conducted daily, usually in the mornings varying between 8.30 a.m. and 11.30 a.m., during the spring, summer and autumn of 2020, by a single observer. Searches were carried out on most days when the weather was sunny or cloudy but not on rainy days. Normal duration of searches was 45-60 min each day during the active year, which was between 5-7 days per week.

\subsection{Statistical Analyses}

In all our analyses, juveniles also included newborn lizards. We considered as "juveniles" all those individuals retaining an immature coloration, predominantly brownish with black spots and whitish stripes, and not, as is the case of adults, predominantly green (with longitudinal whitish stripes in females and more vivid emerald green in males; Figure 1).

Density estimates were calculated by taking into account the number of lizards observed in each transect, using the area calculated as the length of the transect by a width of $1.5 \mathrm{~m}$. Since we did not record a same lizard individual multiple times (see above), our calculations represent the minimum possible density at the study areas that however did not account for the individuals that were hidden at the survey time.

Generalized linear models (hereby GLM [21]) were used to quantify the effects of sampling years and microhabitats (as \% of observations inside each population category) on abundances of the study species inside the study area. A stepwise forward regression 
procedure was used to test the statistical significance of each variable in turn, and those variables that did not correlate significantly to the dependent variable were excluded (Wald test $p>0.05)$. The eventual significant variables were computed using the best subset procedure, and the abundances (number of individuals) were used as dependent variable and the years and the microhabitat categories as predictors. In all models, the identity link function and a Poisson distribution of error were used [22].

A principal coordinates analysis (PCoA) was used to graphically represent the resemblance matrix between lizard individuals by sex, age class, and year of study. In this analysis, the Gower measure was used as distance measure, and the similarity/distance values were raised to the transformation exponent $\mathrm{c}=2$.

Pearson's product moment correlation coefficient was used to test for the correlation between elapsed time (number of years after the beginning of the study) and the lizard density (expressed as the mean number of individuals per transect meter per year). Habitat niche overlap among males, females, and juveniles (pairwise comparisons) was assessed by Pianka's [23] symmetric equation, with values ranging from 0 (no overlap) to 1 (total overlap), but taking into account in the calculations also the relative occurrence of each habitat type (\% of transect length) with the Ecosim 700 software.

To identify changes in lizard numbers during the study period, regression analysis was applied to lizard densities as a dependent variable with year as the independent variable, giving:

$$
\text { Lizard densities }=b+m * \text { year }
$$

where $m$ is the regression coefficient and $b$ the $\mathrm{y}$-intercept. The null hypothesis is that densities were stable when $m=0$; significant departures from $m$ indicate population change. Departures from the 0 coefficient were evaluated using a $t$-test at $n-2$ d.f. derived from:

$$
t=\frac{m-\beta}{\mathrm{s} / \sqrt{ } \sum(\mathrm{x}-\text { mean })^{2}}
$$

where $m$ is the true regression, $\mathrm{s}$ the error attached to $m$, and $\underline{\beta}$ the hypothetical value of 0 [24].

Due to low lizard counts in certain months for the French sample, tests for uniformity of monthly lizard presence in the hedgerow in France were made using a one sample Kolmogorov-Smirnov Goodness of Fit Test $\left(\mathrm{D}_{\max }\right)$. This test avoids cell re-binning, is robust and not sensitive to cell counts. The null hypothesis is equality of cell counts across months with $\alpha=0.05$. Contingency table $\chi^{2}$ test was used to test frequency differences of green lizards among habitat types in central Italy.

Shapiro-Wilk W test was applied to test for the normality of the variables prior to using a parametric analysis of variance (ANOVA) analysis. Analyses were made using Statistica 6.0 and Minitab V17, with alpha set at 5\% in all tests. In the text, means are followed by \pm 1 standard deviation.

\section{Results}

\subsection{Italy}

Overall, the surveyed total transect length was 10,797 $\mathrm{m}$ across the six habitat types, $2234 \mathrm{~m}$ in Rubus, $1894 \mathrm{~m}$ in stony walls, $1822 \mathrm{~m}$ in grasslands, $1806 \mathrm{~m}$ in Cytisus, $1664 \mathrm{~m}$ in Spartium, and $1377 \mathrm{~m}$ in Smilax aspera. The total number of observed individuals was 393, including 118 males, 117 females, and 158 juveniles (Table 1). Adult sex-ratio was 11. Frequencies of lizard sightings varied considerably throughout the year, with adult peaks in April-June, very few adult individuals encountered in August-September, and juvenile peaks from July to September (Figure 2). 


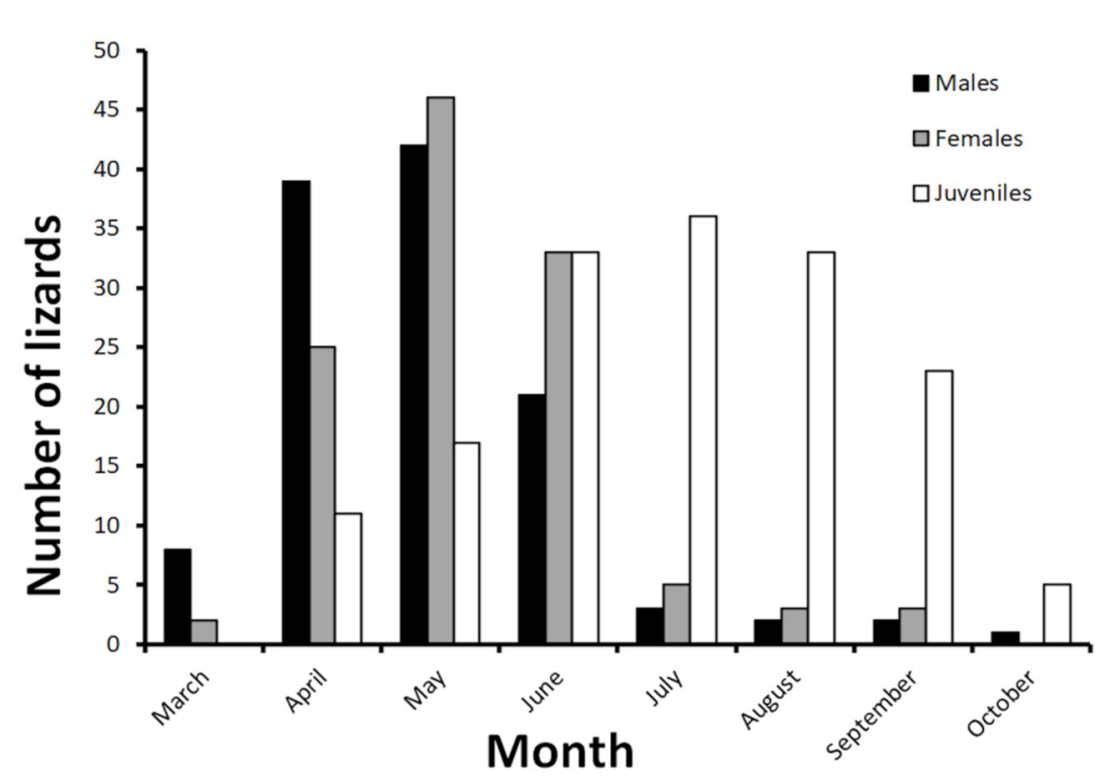

Figure 2. Monthly distribution of the number of lizard sightings at the study area in central Italy. Total sample: males $=118$, females $=117$, juveniles $=158$.

Although the length of the transects was similar among habitat types (see above), the frequencies of individuals observed by habitat type varied considerably (contingency table $\left.x^{2}=150.9, \mathrm{df}=5, p<0.0001\right)$, with adults of both sexes being found especially in Rubus habitat, and juveniles in grasslands (Figure 3). A PCoA (81.38\% of variance explained by Coordinate 1 and $10.07 \%$ by Coordinate 2 ) showed that, independently of the year of sampling, juveniles were arranged in a distant part of the multidimensional space compared to adults of either sexes (Figure 4).

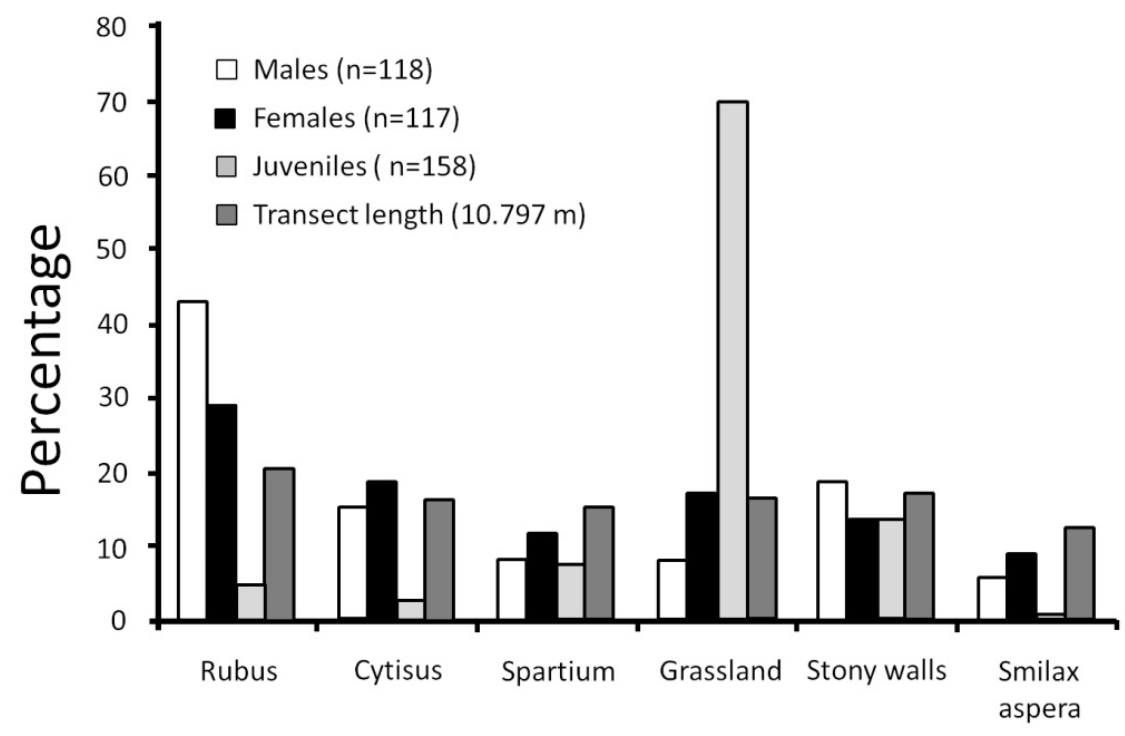

\section{Habitat type}

Figure 3. Percentages of Lacerta bilineata individuals observed in the various habitat types, and in relation to the transect length. Sample sizes for all individuals categories and for transect length are given in the legend. 


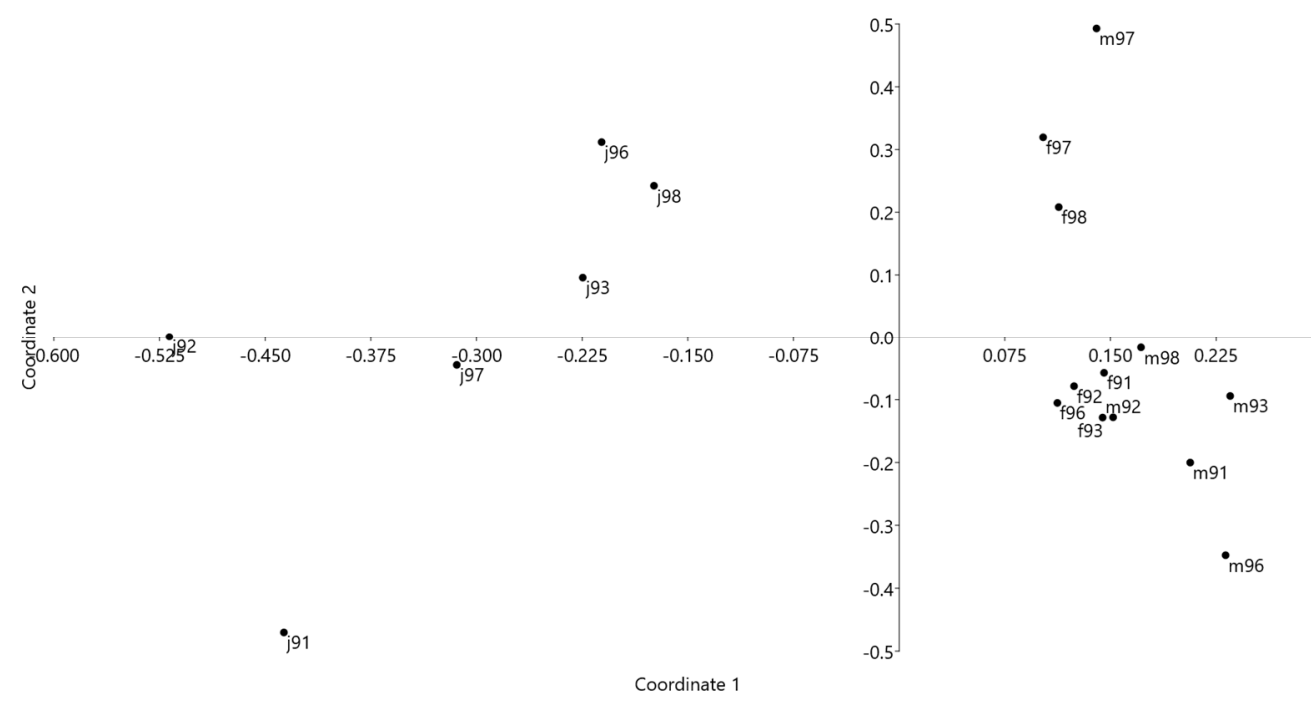

Figure 4. Scatter plot of a principal coordinates analysis (PCoA) graphically representing the resemblance matrix between lizard individuals by sex, age class, and year of study. Symbols: $m=$ males, $f=$ females, $\mathrm{j}=$ juveniles, $91=$ year 1991 , 92 = year 1992, 93 = year 1993, 96 = year 1996, 97 = year 1997, 98 = year 1998.

Pooling all the study years, the habitat niche overlap was very high between males and females $(O=0.929)$, very low between males and juveniles $(O=0.343)$, and intermediate between females and juveniles $(\mathrm{O}=0.554)$. The yearly variations in the overlap values among males, females, and juveniles were relatively minor (Table 2), and, in all years, males versus females exhibited the highest overlap and males versus juveniles the lowest overlap (Table 2). A one-way ANOVA showed that the yearly overlap values differed significantly among the three paired groups $\left(\mathrm{F}_{2,13}=110.3, p<0.0001\right)$, and Tukey HSD post-hoc tests revealed that male-female overlaps were significantly higher than both male-juvenile $(p<0.001)$ and female-juvenile $(p<0.001)$ overlaps, and that male-juvenile overlaps also differed significantly from female-juvenile overlaps $(p<0.001)$.

Table 2. Habitat niche overlap values, by year, among males, females, and juveniles of Lacerta bilineata at the study area in central Italy.

\begin{tabular}{cccc}
\hline Year & Males vs. Females & Males vs. Juveniles & Females vs. Juveniles \\
\hline 1991 & 0.939 & 0.333 & 0.522 \\
\hline 1992 & 0.956 & 0.331 & 0.439 \\
\hline 1993 & 0.924 & 0.193 & 0.473 \\
\hline 1996 & 0.799 & 0.347 & 0.560 \\
\hline 1997 & 0.854 & 0.387 & 0.620 \\
\hline 1998 & 0.885 & 0.339 & 0.621 \\
\hline
\end{tabular}

The GLM results are summarized in Table 3. For both males and females, the GLM results showed that the abundances increased with the increase of Rubus. For the juveniles, the GLM results showed that the abundances increased with the increase of Spartium. Lizard densities throughout the year (Table 4 ) were not linearly correlated $(r=0.359, n=6$, $p=0.486)$. 
Table 3. Results of GLM, analyzing the effects of microhabitat tipologies and years on the abundances of the various population categories of Lacerta bilineata at the study area in central Italy. Only the significant variables are presented in this table.

\begin{tabular}{cccccc}
\hline \multirow{2}{*}{ Male } & & Estimate & St. Error & Wald & $p$ \\
\cline { 2 - 6 } & Intercept & 2.242248 & 0.271097 & 68.40954 & 0.000000 \\
\cline { 2 - 6 } Female & Rubus sp. & 0.081649 & 0.026769 & 9.30322 & 0.002288 \\
\cline { 2 - 6 } & Intercept & 5.474814 & 5.589709 & 0.959313 & 0.327360 \\
\cline { 2 - 6 } Juveniles & Rubus sp. & 2.475033 & 1.008660 & 6.021048 & 0.014136 \\
\cline { 2 - 6 } & Intercept & 19.88394 & 2.535319 & 61.50914 & 0.000000 \\
\cline { 2 - 6 } & Spartium sp. & 3.55803 & 1.036835 & 11.77605 & 0.000600 \\
\hline
\end{tabular}

Table 4. Density variations, expressed as number of individuals observed per $\mathrm{h}^{-1}$, for Lacerta bilineata at the study area in central Italy.

\begin{tabular}{cccc}
\hline Year & Transect Length $(\mathbf{m})$ & Number of Individuals & Density ha $^{-\mathbf{1}}$ \\
\hline 1991 & 2005 & 93 & 23 \\
\hline 1992 & 1792 & 74 & 20 \\
\hline 1993 & 1874 & 66 & 18 \\
\hline 1996 & 1650 & 78 & 23 \\
\hline 1997 & 1752 & 88 & 25 \\
\hline 1998 & 1724 & 48 & 14 \\
\hline
\end{tabular}

Despite the low density estimate of the final year (1998), regression analysis of longterm density changes of all size classes versus year gave a non-significant result, indicating that the population was stable over the study period:

$$
\text { density }=1.12-0.00054 \pm 0.001 \text { year, }
$$

With the test against the 0 value for a hypothetical stable population $t=0.38, p=0.72$.

\subsection{France}

In total, six males and 10 females were photographed and identified in the hedgerow along with two hatchlings between April and October (Table 5). Male sightings were 13 and females 32 . In total $50 \%$ of males were photographed a second time, with one large male photographed a total of six times between April and June, three of which were during May, making it the longest male resident in the hedgerow. Other males were sighted only once or a second time, mostly during July.

Lizard density over the active year averaged $145 \pm 146$ lizards ha $^{-1}$, with a median density of $75 \mathrm{ha}^{-1}$ and $95 \%$ confidence intervals from $38-263 \mathrm{ha}^{-1}$. The sample size was too low to confidently calculate the monthly density variations.

Monthly lizard presence (males and females) in the hedgerow was uneven either in terms of sightings $\left(D_{\max }=0.339, p<0.001\right)$ or presence of identified lizards $\left(D_{\max }=0.316\right.$, $p=0.01$ ) (Figure 5). Against the equality of presence hypothesis, July sightings were 3.11 times greater than expected, with May and June 1.2 and 1.6 times greater, respectively. Females, except for one sighting in August, were not seen during August and September (Figure 5), thus showing a similar phenology as in Italy (Figure 2). 
Table 5. Monthly sightings of individual male and female lizards identified by photographs in the hedgerow habitat in France. In this table, each " $x$ " represents a different and independent sighting event.

\begin{tabular}{|c|c|c|c|c|c|c|c|}
\hline & April & May & June & July & August & Sept & October \\
\hline Male 1 & $x$ & $x x x$ & $x x$ & & & & \\
\hline Male 2 & & & $x$ & & & & \\
\hline Male 3 & & & & $x x$ & & & \\
\hline Male 4 & & & & $x$ & & & \\
\hline Male 5 & & & & $x x$ & & & \\
\hline Male 6 & & & & $x$ & & & \\
\hline Female 1 & $x$ & & $x$ & $x x x x$ & & & \\
\hline Female 2 & & $x x$ & $x$ & $x x$ & $x$ & & \\
\hline Female 3 & & $x x$ & $x x$ & & & & \\
\hline Female 4 & & $x$ & $x x$ & $x x x$ & & & \\
\hline Female 5 & & & $x$ & $x$ & & & \\
\hline Female 6 & & & & $x x$ & & & \\
\hline Female 7 & & & & $x$ & & & \\
\hline Female 8 & & & & $x$ & & & \\
\hline Female 9 & & & & & & & $x$ \\
\hline Female 10 & & & & & & & $x x$ \\
\hline
\end{tabular}

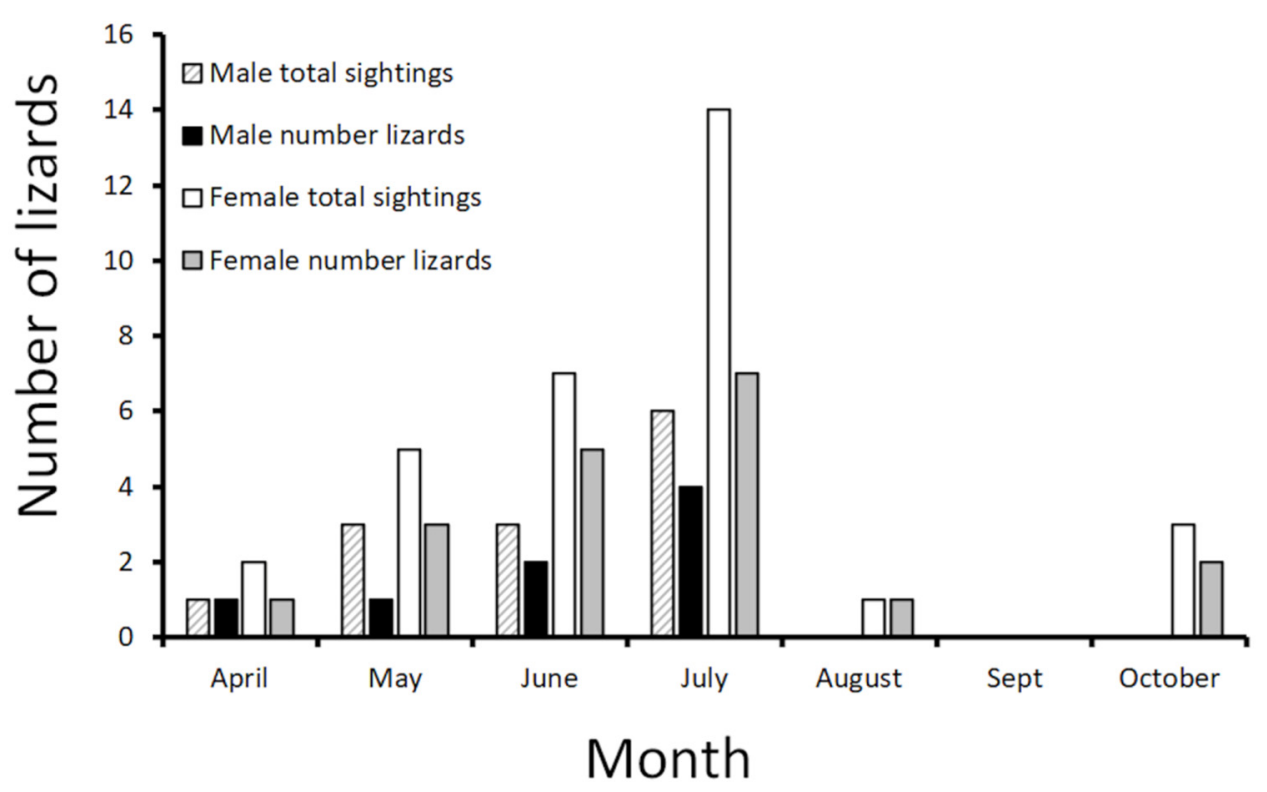

Figure 5. Number of Lacerta bilineata and their sighting frequencies in the hedgerow in France.

In the general study locality, nine individuals were found during periods of high lizard densities with injury signs that were attributable to aggression by conspecifics on the basis of the type of marks left on the victim's body, and presence of the shed tails, which often occur in lizard combats. Some individuals showed no superficial injuries, suggesting they were internal, whilst others were alive with and without superficial injury but semi-conscious (Figure 5). These injuries were not what we would expect if these were a result of predation attempts. 


\section{Discussion}

\subsection{Ecological Considerations}

Our data concerning the Italian population showed three main patterns: (1) a uneven micro-habitat use; (2) an ontogenetic shift in micro-habitat use, from relatively opendry areas (grasslands; juveniles) to relatively closed-moist areas (mainly Rubus habitat for adults); (3) a high similarity in micro-habitat use between males and females, with juveniles being more similar to females than to males. All these three patterns should be discussed in the light of the theory and the empirical data available for the ontogenetic habitat changes of lizards (e.g., [25-27]). Indeed, there is a wealth of studies highlighting that ontogenetic habitat shifts are not unusual in lizards, as they have been observed for instance in Teiidae [25], Scincidae [28], Anolidae [29], Lacertidae [30], Chamaeleonidae [31], Varanidae [32], and Anguidae [33], among others. However, previous data were relatively contrasting even on the same groups of lizards: for instance, in Anolis lizards, some studies documented a clear ontogenetic shift in habitat use (e.g., [29]), whereas other studies did not find any ontogenetic effect on the structural niche use [34].

Several hypotheses, not mutually exclusive, have been advocated to explain ontogenetic shifts in habitat use in lizards: (i) competition avoidance, (ii) competitive interference, (iii) cannibalism, (iv) habitat-specific predation, and (v) habitat-matrix model [29].

The competition-avoidance hypothesis anticipates that the various age-classes and sexes should use different habitat types to reduce competition for similar prey size and taxa. This hypothesis can be only applied to cases of food-limited scenarios (e.g., [35]), and was not universally supported in earlier studies (e.g., [29]). In our study area in central Italy, however, Angelici et al. [8] demonstrated that the diet of juveniles (consisting mainly of spiders, Rhynchota and orthopterans) was significantly different from that of adults of either sexes, which feed essentially upon beetles and isopods. Therefore, the prey preferences exhibited by the green lizards [8] may in theory be consistent with a food niche partitioning pattern, and thus with the competition-avoidance hypothesis. Ontogenetic differences in prey types were also found in other lizard species (e.g., [36]). Data on food habits of our green lizard population from western France are not available.

The competition interference hypothesis predicts that aggression of one size-category or sex over the others may lead to habitat partitioning patterns. For example, juveniles may be aggressively excluded by adults from preferred arboreal perch sites in the canopy, leaving immatures to occupy less contested positions in the grass (e.g., [29]). In central Italy, although we did not collect direct sightings documenting this pattern, the fact that the juveniles were found especially in open-grassy habitat, whereas the adults were found in more structured, bushy habitats might indirectly support this hypothesis. If so, the juvenile green lizards may be pushed outside preferable perch sites within bushes and in the branches of the bushes that are possibly better from both the thermoregulation and the antipredation points of view. Juveniles were rare in the hedgerow in France $(n=2)$ where data also suggest potential conflict between adult males and also male aggression towards females especially when densities are high [9] (Figure 6). For example, the presence of a second male in the hedgerow, when the large "resident" male was present, occurred only once (June) and at the opposite end of the hedgerow from the resident male. Thus, data from both Italy and, more anecdotally, France would provide evidence for the competition interference hypothesis. In the lacertid lizard Zootoca vivipara, population density impacts on numbers due to male aggression towards adult females during high densities [37]. This reduces survivorship and fecundity, leading to population decline [36]. 

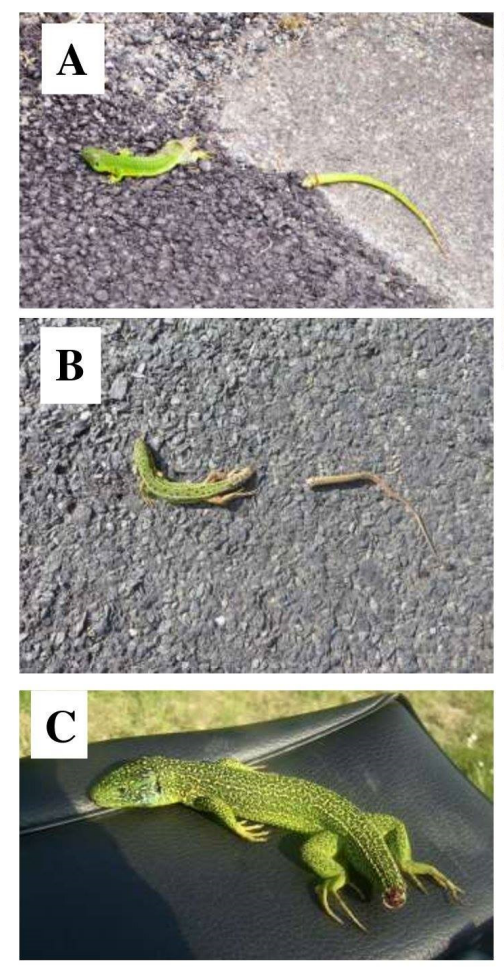
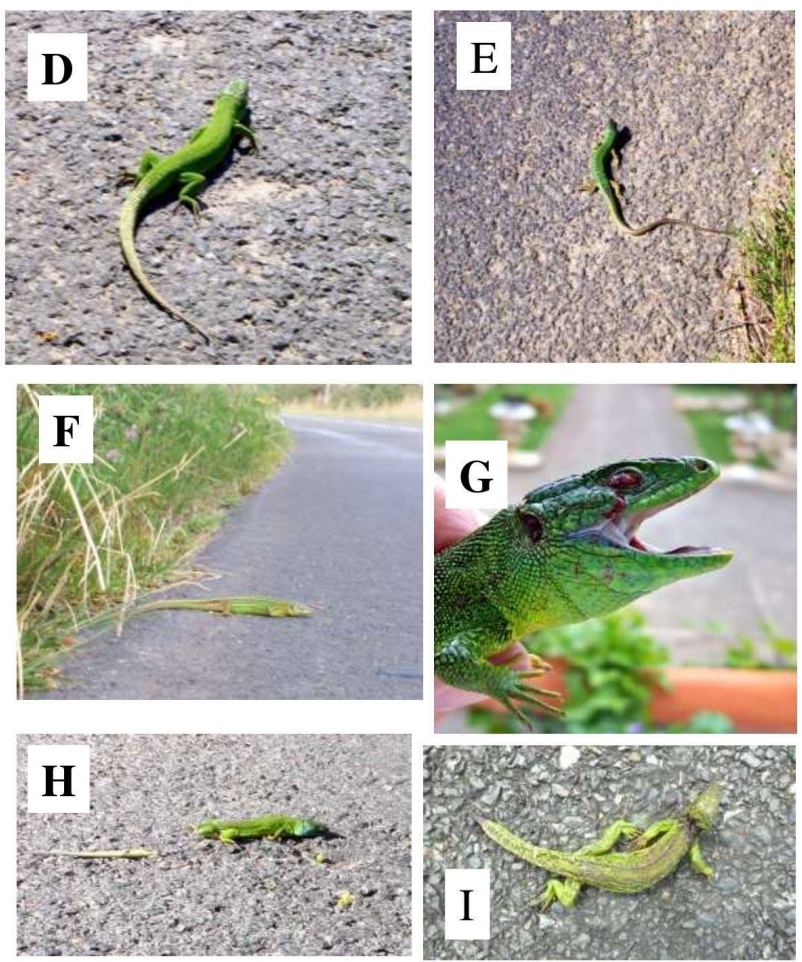

Figure 6. Examples of Lacerta bilineata from Western France that showed injury signs likely resulting from conspecific aggression. All examples except $\mathbf{C}$, which was alongside woodland, were found next to hedgerows. Lizard in $\mathbf{G}$ is from [38]. Except for $\mathbf{G}$, none of these lizards, including those that were dead (lizards A, B, D, E, H, and I), showed any physical injuries except in some instances tail loss, which is a natural reaction to being attacked or stressed in lacertid lizards.

The cannibalism hypothesis suggests that juveniles may select different habitats than adults in order to avoid being preyed upon by their larger conspecifics $[31,39,40]$. Although this hypothesis has been rejected by previous studies on lizards [29], at our study area in central Italy, cannibalism occurred in the diet of $2.4 \%(n=61)$ of the individuals that were examined [8], and in Western France, the signs of intraspecific aggression (Figure 6) [40] may indirectly suggest that cannibalism may also occur too. Thus, the cannibalism hypothesis also seems to be supported in our study case.

The habitat-specific predation hypothesis (e.g., [41]) cannot be adequately tested by our research study, because we did not quantify the predation risks for the various L. bilineata age-classes in the various micro-habitat types and in either study areas. However, it is noteworthy that the same preference for more open areas by juveniles in comparison with the adults mirrors data on Anolis aeneus [41].

The habitat-matrix model hypothesis $[29,42]$ postulates that the structural habitat matrix of a given species selects for a predictable morphological phenotype, optimizing whole body performance within the given microhabitat. Since we did not analyze the morphological phenotypes of the lizards at our study area, we cannot test this hypothesis. In general, however, our data suggest that the observed ontogenetic structural niche pattern may have more than one causal factor, including competition avoidance, competition interference, and cannibalism. The persistence of the same patterns across years demonstrates a temporal stability of the ontogenetic structural niche pattern, and suggests that the observed patterns may be widespread among wild populations of L. bilineata.

\subsection{Conservation Considerations}

In western Europe, the anthropogenic modification of the landscape since hundreds years has resulted in much of the countryside consisting of fragments of once continuous habitat $[43,44]$. This fragmented habitat may have strongly influenced the persistence and 
distribution of wild animal populations, and several studies showed, mostly anecdotally, evidence of positive local population effects and indicated that some species use hedgerows as movement conduits [44-46].

Although most studies on the role of hedgerows have been carried out on mammals and birds [45,46], it is clear that these elements of the landscape are crucial for European reptile species as well [47]. Hedgerow systems are crucial habitats in fragmented landscapes in supporting green lizard populations, especially in agricultural and semi-agricultural landscapes. Indeed, and despite the obvious climatic differences between the two study areas, our data revealed that the apparent density of green lizard was much higher in the hedgerows than in the mosaic habitat of central Italy. The major differences in population densities of $L$. bilineata between the hedgerow in France and the mosaic habitat in Italy was unexpected and potentially important to our understanding of the impacts of major habitat change through man-made activities. The increased densities and high territorial behaviour in L. bilineata, may impact on spacing patterns/home territories in this species. The frequent finding of seriously injured or dead individuals (Figure 6) that was observed in France (and much less in Italy), likely due to intra-specific aggression, in L. bilineata has been reported previously [43]. In the present study locality in France, the absence of individuals in close proximity in the hedgerow-individuals were seen only once basking or in shaded areas in close proximity - is probably due to intra-specific tensions ([43]; Meek and Luiselli unpublished data). The finding of higher densities and hence possible smaller territories in anthropogenic modified environments probably exacerbate this dynamic. Other lacertids also show similar intra-specific aggression and strong territorial behavior $[9,43,45]$.

The surrounding agricultural land has limited or zero value as habitat for reptiles [45], and indeed no lizards were seen on the agricultural areas bordering the hedgerow in France. Mirroring the French data, in Italy the adults of both sexes used open grasslands rarely, whereas the juveniles did (possibly for minimizing interactions with adults, see above). Thus, although less utilized than hedgerows or Rubus bushes, open agricultural lands are also important for the optimal management of the green lizard populations. Some species of lizard apparently thrive in human altered habitats using road and rail networks as movement pathways [46,47]. At present these comments are tentative but must merit investigation in future studies. As a habitat generalist, L. bilineata may be better adapted to farmland disturbance and to live in hedgerows in fragmented landscapes than other reptiles. Edge habitats in natural areas are clearly a key to population persistence [6]. In the area surrounding the hedgerow in France, L. bilineata individuals were found in greater numbers than expected in hedgerows alongside roads [11]. Previously, hedgerows have been perceived primarily as movement pathways between prime habitat [48-50], but it is apparent they can be important habitat for L. bilineata during at least the reproductive period [49,50].

It is clear that a careful management of hedgerows and bushy ecotones surrounding forested patches is crucial in order to avoid further declines of the green lizard populations in both France and Italy. Since cultivated land with hedges harbored the highest lizard diversity in other European studies [51], a careful management of the hedgerows and ecotones may certainly be beneficial for lizards in general, and not only for the green lizards. Replanting programs have been widely used in order to attempt to restore hedgerow habitats, but the methods to be employed should take into serious consideration the ecological needs of the target species. For instance, replanting programs have often failed to replace complex matrices of stones, logs, and roots that are typically found along the base of the hedges and that are key refuges for the lizards (and other reptile species) [52,53], especially as basking microhabitats, shelters from predators, and during the winter for hibernation [54]. For green lizards, the key requirement is to maintain a structurally diverse habitat, providing a mix of open areas close to vegetation cover, with different bush species that provide a wide range of humidity and coverage [54].

The Italian dataset revealed that adults versus juveniles selected preferentially different bush species-dominated habitats for their activities. Although it is generally considered 
that for lizards (and reptiles in general), the actual plant species present are less important than the physical influence they create [55], in the case of green lizards, we demonstrated that plant species are very relevant, as they emerged as significant factors in the habitat use for males and females (Rubus sp.) as well as for juveniles (Spartium sp.). Green lizards were also habitat generalists in our study, and in Northern Italy, earlier studies also showed that their conspecifics positively select rocks representing a suitable habitat for thermoregulation and sheltering [6]. Instead, stony walls (that are the prominent human-made features in the landscape) were less used at our Italian study site than natural habitats dominated by Rubus or Spartium. However, approximately the same percentage of individuals of all categories (15-20\%) used stony walls, showing that this artificial habitat feature is of some importance for these lizards. In particular, on two occasions, we observed females ovipositing eggs at the base of these walls, thus suggesting that stony walls may be important habitats for the reproduction of green lizards at the Italian sites. The comparative evidence from these studies shows that very local (habitat and climatic) conditions may strongly condition the ecological requirements of green lizards, and consequently that site-specific studies should always be carry out for a reliable management of the various L. bilineata populations. In this regard, in the closely-related Lacerta viridis, there was evidence of higher specialization degree in peripheral populations compared with populations in the core, with peripheral populations exhibiting a higher sensitivity to habitat loss, especially at small spatial scale [55]. Further studies should explore whether the same pattern occurs in L. bilineata populations.

As a conservation measure, public awareness of key habitats in fragmented landscapes cannot be overstated. Farmers can easily remove a hedgerow with little concern by the authorities or local people, but developers removing woodland are a different matter both in legal terms and for public concern. Hedgerows are not just corridors for animals to access prime habitat [50], they are also a year-round habitat for many species, not just L. bilineata in this study, but also Podarcis muralis (that is present all year round), and the snakes Hierophis viridiflavus, Natrix helvetica, and Vipera aspis are frequent visitors. Hedgerows therefore play a crucial part in population persistence. Information from genetic studies indicates isolated populations of reptiles, even in prime habitat as in our Italian study area, will gradually lose genes through "drift" and become inbred with reduced fitness, risking extinction $[38,56,57]$. Thus, the role of hedgerows in maintaining metapopulation structure in such landscapes is of prime importance [43]. Habitat protection is difficult to achieve, but a general solution proposed [43] is that herpetological or other organizations should be encouraged to purchase as many natural areas as possible and thus increase the community of ecologists stake in the future of reptiles and other life forms. This is currently a policy, for instance, of the British Herpetological Society in the UK.

Author Contributions: Conceptualization: L.R., M.C., R.M. and L.L.; methodology: L.L., R.M. and R.M.; formal analysis: M.D.V., R.M. and L.L.; investigation: L.R., M.C., D.D., L.L. and R.M.; writingoriginal draft preparation: L.L. and R.M.; writing—review and editing: all authors; supervision: L.L. All authors have read and agreed to the published version of the manuscript.

Funding: No funds were secured for this research study.

Institutional Review Board Statement: Since no lizard individual was captured or handled during the execution of this study either in France or in Italy, no such statement or any authorization to carry our the research was required.

Informed Consent Statement: Not applicable.

Data Availability Statement: The data presented in this study are reported in the tables and figures. Data not shown in tables are available on request from the corresponding author. The data are not publicly available due to ongoing longitudinal analysis. 
Acknowledgments: The authors are indebted with two anonymous referees for having greatly improved the submitted draft. The authors are also thankful to Umberto Agrimi, Claudio Anibaldi, Dario Capizzi, and Arianna Ceccarelli for having contributed to the field data collecting at the Italian study area. Since this study did not involve capture or disturbance of the involved lizards, no permits were needed from the pertinent governmental agencies in both Italy and France.

Conflicts of Interest: The authors declare no conflict of interest.

\section{References}

1. Doherty, T.S.; Balouch, S.; Bell, K.; Burns, T.J.; Feldman, A.; Fist, C.; Garvey, T.F.; Jessop, T.S.; Meiri, S.; Driscoll, D.A. Reptile responses to anthropogenic habitat modification: A global meta-analysis. Glob. Ecol. Biogeog. 2020, 29, 1265-1279. [CrossRef]

2. Luiselli, L.; Vignoli, L.; Rugiero, L.; Meek, R. Declining occupancy rates in the hibernacula of aspic vipers (Vipera aspis) in Italy and France; evidence for climatic effects? Herpetol. J. 2018, 28, 137-142.

3. Pérez-Mellado, V.; Cheylan, M.; Geniez, P.; Nettmann, H.K.; Schmidt, B.; Podloucky, R.; Sindaco, R.; Romano, A. Lacerta bilineata. In IUCN 2012. IUCN Red List of Threatened Species; Version 2012.2.; IUCN: Gland, Switzerland, 2009; Available online: www.iucnredlist.org (accessed on 14 December 2020).

4. Sacchi, R.; Marchesi, M.; Gentilli, A.; Pellitteri-Rosa, D.; Scali, S.; Borelli, A. Western green lizards (Lacerta bilineata) do not select the composition or structure of the ecotones in Northern Italy. North West. J. Zool. 2011, 7, 213-221.

5. Pernat, A.; Sellier, Y.; Préau, C.; Beaune, D. Effet du pâturage sur le lézard vert occidental (Lacerta bilineata Daudin, 1802) (Squamata: Lacertidae) en milieu de landes. Bull. Soc. Herpétol. Fr. 2017, 161, 57-66.

6. Luppi, M.; Gentilli, A.; Bogliani, G. Microhabitat selection of the Western green lizard Lacerta bilineata. Nat. Hist. Sci. 2020, 7, 3-10. [CrossRef]

7. Verwaijen, D.; Van Damme, R. Foraging mode and its flexibility in Lacertid lizards from Europe. J. Herpetol. 2008, 42, 124-133. [CrossRef]

8. Angelici, F.M.; Luiselli, L.; Rugiero, L. Food habits of the green lizard, Lacerta bilineata, in central Italy and a reliability test of faecal pellet analysis. Ital. J. Zool. 1997, 64, 267-272. [CrossRef]

9. Meek, R. Temporal trends in Podarcis muralis and Lacerta bilineata populations in a fragmented landscape in western France: Results from a 14 year time series. Herpetol. J. 2020, 30, 20-26. [CrossRef]

10. Luiselli, L.; Rugiero, L. Null model analysis of lizard communities in five urban parks of Rome. Amphib. Reptil. 2007, 28, 547-553. [CrossRef]

11. Meek, R. Temporal distributions, habitat associations and behaviour of the green lizard (Lacerta bilineata) and wall lizard (Podarcis muralis) on roads in a fragmented landscape in Western France. Acta Herpetol. 2014, 9, 179-186.

12. Rugiero, L.; Capula, M.; Capizzi, D.; Amori, G.; Milana, G.; Lai, M.; Luiselli, L. Long-term observations on the number of roadkilled Zamenis longissimus (Laurenti, 1768) in a hilly area of central Italy. Herpetozoa 2018, 30, 212-217.

13. Rugiero, L.; Milana, G.; Capula, M.; Amori, G.; Luiselli, L. Long term variations in small mammal composition of a snake diet do not mirror climate change trends. Acta Oecol. 2012, 43, 158-164. [CrossRef]

14. Rugiero, L.; Milana, G.; Petrozzi, F.; Capula, M.; Luiselli, L. Climate-change-related shifts in annual phenology of a temperate snake during the last 20 years. Acta Oecol. 2013, 51, 42-48. [CrossRef]

15. Capula, M.; Rugiero, L.; Capizzi, D.; Franco, D.; Milana, G.; Luiselli, L. Long-term, climate-change-related shifts in feeding frequencies of a Mediterranean snake population. Ecol. Res. 2016, 31, 49-55. [CrossRef]

16. Capula, M.; Rugiero, L.; Capizzi, D.; Milana, G.; Vignoli, L.; Franco, D.; Petrozzi, F.; Luiselli, L. Long-term, climate change-related shifts in monthly patterns of roadkilled Mediterranean snakes (Hierophis viridiflavus). Herpetol. J. 2014, $24,97-102$.

17. Luiselli, L.; Capizzi, D. Influences of area, isolation and habitat features on distribution of snakes in Mediterranean fragmented woodlands. Biodiv. Conserv. 1997, 6, 1339-1351. [CrossRef]

18. McBrayer, L.D.; Parker, S.E. Variation in habitat management alters risk aversion behavior in lizards. Behav. Ecol. Sociobiol. 2018, 72, 1-9. [CrossRef]

19. Bonnet, X.; Billy, G.; Lakušić, M. Puncture versus capture: Which stresses animals the most? J. Comp. Physiol. B 2020. [CrossRef]

20. Rugiero, L.; Capula, M.; Dendi, D.; Petrozzi, F.; Di Vittorio, M.; Luiselli, L. A 28-years-long monitoring study suggests heavy decline and habitat shifts in three populations of a Mediterranean tortoise species. Anim. Biol. 2021, 71, 21-35. [CrossRef]

21. Hosmer, D.W.; Lemeshow, S. Applied Logistic Regression Analysis, 2nd ed.; John Wiley and Sons: Hoboken, NJ, USA, 2000.

22. McCullagh, P.; Nelder, J.A. Generalized Linear Models; Chapman and Hall/CRC: London, UK, 1989.

23. Pianka, E.R. Niche overlap and diffuse competition. Proc. Natl. Acad. Sci. USA 1974, 71, 2141-2145. [CrossRef]

24. Bailey, N.T.J. Statistical Methods in Biology; Cambridge University Press: Cambridge, UK, 1995; p. 255.

25. Paulissen, M.A. Ontogenetic and seasonal shifts in microhabitat use by the lizard Cnemidophorus sexlineatus. Copeia 1988, 1988, 1021-1029. [CrossRef]

26. Irschick, D.J.; Macrini, T.E.; Koruba, S.; Forman, J. Ontogenetic differences in morphology, habitat use, behavior, and sprinting capacity in two West Indian Anolis lizards. J. Herpetol. 2000, 34, 444-451. [CrossRef]

27. Smith, G.R.; Ballinger, R.E. The ecological consequences of habitat and microhabitat use in lizards: A review. Contemp. Herpetol. 2001, 3, 1-27. [CrossRef]

28. Law, B.S. Habitat Shift in the Eastern Australian Water Skink (Eulamprus quoyii)? Copeia 1991, 1991, 1117-1120. [CrossRef] 
29. Jenssen, T.A.; Hovde, K.A.; Taney, K.G. Size-related habitat use by nonbreeding Anolis carolinensis lizards. Copeia 1998, 1998, 774-779. [CrossRef]

30. Nemes, S.; Vogrin, M.; Hartel, T.; Ölerer, K. Habitat selection at the sand lizard (Lacerta agilis): Ontogenetic shifts. North-West. J. Zool. 2006, 2, 17-26.

31. Keren-Rotem, T.; Bouskila, A.; Geffen, E. Ontogenetic habitat shift and risk of cannibalism in the common chameleon (Chamaeleo chamaeleon). Behav. Ecol. Sociobiol. 2006, 59, 723-731. [CrossRef]

32. Imansyah, M.J.; Jessop, T.S.; Ciofi, C.; Akbar, Z. Ontogenetic differences in the spatial ecology of immature Komodo dragons. J. Zool. 2007. [CrossRef]

33. Kolanek, A.; Bury, S.; Turniak, E.; Szymanowski, M. Age-dependent utilization of shelters and habitat in two reptile species with contrasting intraspecific interactions. Animals 2019, 9, 995. [CrossRef]

34. Powell, G.L.; Russell, A.P. Locomotor correlates of ecomorph designation in Anolis: An examination of three sympatric species from Jamaica. Can. J. Zool. 1992, 70, 725-727. [CrossRef]

35. Andrews, R.M. Growth rate in island and mainland lizards. Copeia 1976, 1976, 477-482. [CrossRef]

36. Lathi, M.E.; Beck, D.D. Ecology and ontogenetic variation of diet in the pigmy short-horned lizard (Phrynosoma douglasii). Am. Midl. Nat. 2008, 159, 327-339.

37. Le Galliard, J.-F.; Fitze, P.S.; Ferriere, R.; Clobert, J. Sex ratio bias, male aggression, and population collapse in lizards. Proc. Natl. Acad. Sci. USA 2005, 102, 18231-18236. [CrossRef] [PubMed]

38. Meek, R. Natural History Note; Lacerta bilineata (western green lizard): Field injury. Herpetol. Bull. 2011, 116, 40-41.

39. Mitchell, J.C. Cannibalism in reptiles: A worldview review. St. Amphib. Reptiles Herpetol. Cir. 1986, 15, 1-23.

40. Beebee, T.J.C.; Griffiths, R.A. Amphibians and Reptiles; Harper-Collins: London, UK, 2000.

41. Stamps, J.A. The relationship between onto- genetic habitat shifts, competition and predator avoidance in a juvenile lizard (Anolis aeneus). Behav. Ecol. Sociobiol. 1983, 12, 19-33. [CrossRef]

42. Pounds, J.A. Ecomorphology, locomotion, and microhabitat structure: Patterns in a tropical mainland Anolis community. Ecol. Monogr. 1988, 58, 299-320. [CrossRef]

43. Simberloff, D.; Cox, J. Consequences and costs of conservation corridors. Conserv. Biol. 1987, 1, 63-71. [CrossRef]

44. Spellerberg, I.F. The Ecological Effects of Roads; Science Publishers: Enfield, NH, USA, 2002.

45. Davies, Z.G.; Pullin, A.S. Are hedgerows effective corridors between fragments of woodland habitat? An evidence-based approach. Landsc. Ecol. 1987, 22, 333-351. [CrossRef]

46. Delgado Garcia, J.D.; Arevalo, J.R.; Fernandez-Palacios, J.M. Road edge effect on the abundance of the lizard Gallotia gallotia in two Canary Islands forests. Biodivers. Conserv. 2007, 16, 2949-2963. [CrossRef]

47. Gherghel, I.; Strugariu, A.; Sahlean, T.C.; Zamfirescu, O. Anthropogenic impact or anthropogenic accommodation? Distribution expansion of the common wall lizard (Podarcis muralis) by artificial habitats in the north-eastern limits of its distribution range. Acta Herpetol. 2009, 4, 183-189.

48. Saint Girons, H. Structure et évolution d'une petite population de Vipera aspis (L.) dans une région de bocage de l'ouest de la France. Rev. Écol. 1996, 61, 223-241.

49. Saint Girons, H.; Bradshaw, S.D. Sédentarité, déplacements et répartition des individus dans une population de Lacerta viridis (Laurenti, 1768) (Lacertilia, Lacertidae). Bijdr. Dierkd. 1989, 59, 63-70. [CrossRef]

50. Saint-Sirons, H.; Castanet, J.; Bradshaw, S.D.; Baron, J.P. Démographie comparée de deux populations françaises de Lacerta viridis (Laurenti, 1768). Rev. Écol. 1989, 44, 361-386.

51. Michaelides, G.; Kati, V. Diversity patterns and conservation management of the lizard community in a Mediterranean reserve (Cyprus). J. Biol. Res. Thessalon. 2009, 12, 211-220.

52. Lecq, S.; Loisel, A.; Brischoux, F.; Mullin, S.J.; Bonnet, X. Importance of ground refuges for the biodiversity in agricultural hedgerows. Ecol. Ind. 2017, 72, 615-626. [CrossRef]

53. Lecq, S.; Loisel, A.; Mullin, S.J.; Bonnet, X. Manipulating hedgerow quality: Embankment size influences animal biodiversity in a peri-urban context. Urban For. Urban Green. 2018, 35, 1-7. [CrossRef]

54. Edgar, P.; Foster, J.; Baker, J. Reptile Habitat Management Handbook; Amphibian and Reptile Conservation: Bournemouth, UK, 2010.

55. Prieto-Ramirez, A.M.; Röhler, L.; Cord, A.F.; Péer, G.; Rödder, D.; Henle, K. Differential effects of habitat loss on occupancy patterns of the eastern green lizard Lacerta viridis at the core and periphery of its distribution range. PLoS ONE 2020, 15, e0229600. [CrossRef] [PubMed]

56. Madsen, T.; Stille, B.; Shine, R. Inbreeding depression in an isolated population of adders Vipera berus. Biol. Conserv. 1996, 75, 113-118. [CrossRef]

57. Miller, K.A.; Chapple, D.G.; Towns, D.R.; Ritchie, P.A.; Nelson, N.J. Assessing genetic diversity for conservation management: A case study of a threatened reptile. Anim. Conserv. 2009, 12, 163-171. [CrossRef] 